\title{
Selected Reference Books of 1974-75
}

$\mathrm{T}_{\mathrm{H}}$ HIS ARTICLE CONTINUES the semiannual series originally edited by Constance M. Winchell. Although it appears under a byline, the list is actually a project of the Reference Department of the Columbia University Libraries, and notes are signed with the initials of the individual staff members. ${ }^{1}$

Since the purpose of the list is to present a selection of recent scholarly and foreign works of interest to reference workers in university libraries, it does not pretend to be either well balanced or comprehensive. A brief roundup of new editions of standard works, continuations, and supplements is presented at the end of the column. Code numbers (such as AA71, 2BD89) have been used to refer to titles in the Guide to Reference Books and its supplements. $^{2}$

\section{BIBLIOGRAPHY}

U.S. Library of Congress. Monographic Series. Jan./Mar. 1974- . Wash., 1974- . 3 quarterly issues and annual cumulation. $\$ 100$ per yr. $74-652501$.

At head of title: Library of Congress catalogs.

Although references to numbered monographic serial titles are included in New Serial Titles, citations to individual works in those series are not given and are often

1. Patricia Clark, Diane Goon, Rita Keckeissen, Anita Lowry, Eileen McIlvaine, Doris Ann Sweet, Barbara Wendell; Lehman Library, Mary Ann Miller; Physics Library, Laura Binkowski.

2. Constance M. Winchell, Guide to Reference Books (8th ed.; Chicago: ALA, 1967); Supplement I (Chicago: ALA, 1968); Supplement II (Chicago: ALA, 1970); Supplement III (Chicago: ALA, 1972). difficult to find. As a step toward further bibliographic control over monographs which have been cataloged by the Library of Congress as parts of series, Monographic Series will be hailed by catalogers and acquisitions and reference librarians alike. Utilizing reproductions of printed cards, this is a compilation of titles which have recently been cataloged or for which printed cards have been recently revised. Even though most of the entries in the 1974 issues are 1973 imprints, many older works, especially foreign-language materials, are included. Broader coverage and frequent appearance give it a decided edge over Baer's Titles in Series (Guide AA12) for recent materials.

Logically, this alphabetical listing of series is organized by arranging the monographs under the appropriate series heading. Numbered series titles have been listed numerically and unnumbered series titles in alphabetical order by main entry. Where Library of Congress uses the corporate body rather than the series title for a series heading, appropriate cross-references are made. Since criteria for inclusion embrace not only tracings for series added entries on the card, but also the presence of a series statement, many publishers' series have been included. The compilation is a boon to all librarians who have struggled with identification of titles in series; one expects that it will be used often and will become a standard reference tool for bibliographic searching. $-B . W$.

\section{Libraries AND ARCHIVES}

Archive. Archive im deutschsprachigen Raum. 2. Aufl. Berlin, W. de Gruyter, 1974. 2v. (1418p.) \$200. 73-90262.

At head of title: Minerva-Handbücher.

The second edition of this guide (the first edition appeared in 1932 as Minerva- 
Handbücher, 2. Abt.; Guide AC13) is welcome both for its expanded coverage and the updated information it provides for war-damaged archives in Germany (East and West) and the surrounding regions that have played a significant role in Germany's past-Austria, Switzerland, Luxemburg, Liechtenstein, and, to a lesser degree, Poland and Czechoslovakia. Altogether, some 8,000 archives are listed. Of these, about 2,000 are described in some detail. This edition includes many kinds of archives excluded from the first, primarily archives of a private rather than public nature, such as business, theater, film, and political party archives. All are indexed by type (city, church, etc.), by geographic region, and alphabetically by name. The main section of the work, however, is arranged by city and includes only those archives for which descriptions are provided. These descriptions summarize the history of the archive, indicate what bibliographical aids are available to researchers, and briefly survey the holdings. Citations are given to any detailed accounts of holdings which have been published. It is regrettable, especially considering the high cost, that descriptions could not have been provided for all the archives listed. Even as it stands, however, this guide will be extremely useful and ought to be owned by any large research library.-D.A.S.

Lewanski, Richard Casimir, comp. Guide to Polish Libraries and Archives. Boulder, Colo., East European Quarterly (distr. by Columbia University Pr.), 1974. 209p. (Joint Committee on Eastern Europe of the American Council of Learned Societies and the Social Science Research Council. East European publ. ser., 2) \$11. 73-91484.

This book aims to be a comprehensive guide to repositories of manuscripts and printed records in Poland. Emphasis is on sources in Polish history, civilization, and society, with some attention to other East European countries bordering on Poland or sharing periods of common history and heritage. Excluded are collections in the pure sciences, technology, and agriculture except when they deal with the historical aspect of these topics. Also omitted are collections of foreign materials.
The main body of the work is a schematic listing of libraries arranged alphabetically by name of city or town in which they are located. A typical entry includes address and telephone number of the library; name of director; brief history of the institution; a subject profile; numerical estimate of holdings; special collections; annual growth in volumes; reader services available (e.g., card catalogs, printed bibliographies, admission policies, hours, interlibrary loan, photocopy and microfilm facilities); and a short bibliography of publications by and about the library and its areas of strength. A drawback is the brief subject index. This does not immediately direct one into the main body of the guide but is coded to an outline of cities and libraries listed after the preface. Moreover, there is no explanation of this fact to aid the user.

Information was derived from questionnaires and personal visits by the compiler. It is the first of three planned surveys, under the general editorship of Paul Horecky, of East European resources in libraries abroad, in the United States, and in Canada. As English-language directories, these should prove to be valuable time-saving location indicators, facilitating in-depth scholarship and opening up new avenues of research.-L.M.B.

Meckler, Alan M. and McMullin, Ruth. Oral History Collections. N.Y., Bowker, 1975. 344p. \$29.50. 74-32128.

Designed to help close "the gap between the development of oral history and the information available about it" (Foreword), this work is more ambitious in purpose than the Oral History Association's 1971 pioneer Directory. Like the latter, it provides (in Section II) a directory, but the larger Section I serves as a name and subject index to the information collected by questionnaire concerning the thousands of interviews in the several hundred collections of the United States and sixty-one in four foreign countries. Both sections must be searched, since information applicable to all materials in a collection appears in the directory, and information on a specific name or subject appears in the index. A welcome feature is the inclusion of known additional locations of materials in some entries. 
Inevitably, information is uneven, with many centers inadequately described, but with well-indexed collections represented by full descriptions of major projects. Since a reference work in oral history is bound to be out of date by the time it is released, frequent revision and uniform reporting will be necessary if usefulness is to be maintained. The reader is still urged to write to the individual oral history center for specific information.- R.K.

\section{Data Files}

Directory of Computerized Data Files d Related Software, 1974- . [Washington], National Technical Information Service, 1974- . Annual. \$60. 74-642648.

Government agencies have often collected and processed information for internal use. Although a great number of computergenerated government publications have resulted from these efforts, today's researchers have found that they need more tabulated data than have been made available through printed sources. To fill this information gap, sixty agencies are now making available to the public over 500 machinereadable data files. This annual, the first of its kind, has been published as a guide to the available files and related software.

In the "Abstract Section" the files have been arranged according to subject fields covering demography, social sciences, government, economics, and science and technology. In this first volume there are no listings for many of the seventy-two projected subject fields, but one assumes that when the directory is revised to include all government agencies, data files in almost all areas will be available. Within a subject field entries are arranged by catalog reference number, the first element of which is an acronym for the generating agency. Information includes file title, date of file, a physical description of the file, generating agency name and file number, and information on availability. Price information is provided only in those cases where the data file is being distributed by NTIS. Also indicated in some instances are the sources from which the data were drawn and whether or not software (i.e., programs or format statements) are available. There are indexes by generating agency, by subject, and by catalog reference number.

It is readily apparent that this directory is most useful to those researchers and institutions which have the necessary computers and programmers at their disposal. The latter are essential because many of the data files are sold without software or with software which must be modified to the needs of the individual researcher. Institutions which do not have the hardware, staff, or budget will have to content themselves with citations to the publications which have been generated from some of the files. On the whole, though useful, the directory is not always easy to decipher. Inconsistencies in typography and the way in which files are described will lead many users to hope for changes and improvements in the future. $-B . W$.

\section{NEWSPAPER INDEX}

Zeitungs-Index. Jahrg. 1- , Jan./Marz 1974- . Pullach bei München, Verlag Dokumentation, 1974- . Quarterly. DM 148 per yr.

Willi Gorzny, ed.

Major articles in nineteen German-language newspapers (many of them weeklies, and including the news magazine Der Spiegel) are indexed by subject in this new publication. In addition to papers of more than regional interest from the principal cities of West Germany, Zürich is represented by two titles and Vienna by one. Under topical headings or personal and geographic names used as subjects, arrangement is chronological; entry includes author (for the high percentage of signed articles), title (often with subtitle to give a better idea of content), abbreviated newspaper title, issue number, date, and pagination. See and see also references are used freely; each article appears to be indexed under a single heading only. No plans for cumulating the quarterly issues are indicated, but a number of annual indexes-author, subject, geographical-are promised.-E.S.

\section{Government Documents}

Lombardi, Mary. Brazilian Serial Documents: A Selective and Annotated Guide. 
Bloomington, Indiana Univ. Pr., 1974. 445p. \$15. 73-16533.

This is a successful attempt to provide a guide to serial documents of permanent research value which have been issued by agencies of the Brazilian federal government. Chock-full of information, it may also prove helpful in answering questions concerning the structure of the Brazilian government. The arrangement of the guide follows the organization of the government: the nation as a whole, then the legislative, executive, and judicial branches. Within each part, component agencies are treated according to a hierarchical outline. The table of contents provides an outline of the entire government. For almost every agency a brief history is given, including name changes and dates and titles of pertinent legislation. The serials are then listed, usually alphabetically by title, with as much information as it was possible to obtain. This includes title variations (with crossreferences to superseded and superseding titles), frequency, and availability of indexing, etc. Since the compiler did most of her research for this guide in Brazil, she was unable to include locations in American libraries; instead, she has noted the corresponding item numbers in more general union lists. There is an appendix listing libraries and books consulted, and an index to serial titles and agency names.-P.A.C.

\section{BIOGRAPHY}

Garraty, John A., ed. Encyclopedia of American Biography. New York, Harper \& Row, [1974]. 1241p. \$22.50. 74-1807.

Presented as "an estimation of the major figures of American history as seen from the perspective of the mid-1970's," this dictionary of more than a thousand short biographies of persons, past and present, in all fields, is "intended to aid readers who want to know the whys, not merely the whats, about the significant figures of our history." -Introd. To make this interpretive feature clear, biographies are subdivided: first a concise, factual account incorporating name, dates, education, career, and achievements (these sections prepared by graduate students); then an expert's evaluation of the subject's achievement and importance. The evaluations were written by scholars, are signed, contain a system of cross-references to other names included, and refer to the standard biography. Standards for inclusion are stated as: significance, achievement, fame, and typicality-criteria weighted differently in different cases, but with influence or significance the deciding factor. The work should prove a handy compendium in a reference collection.R.K.

\section{LITERATURE}

Bleznick, Donald William. Sourcebook for Hispanic Literature and Language: A Selected, Annotated Guide to Spanish and Spanish American Bibliography, Literature, Linguistics, Journals, and Other Source Materials. Philadelphia, Temple Univ. Pr., [1974]. 183p. \$15. 74-77776. In preparing this book, Bleznick planned "a practical guide to bibliography and other basic materials which would serve budding and even mature Hispanists in literary and linguistic research."-Pref. (Italics are the reviewer's.) The usual items expected in a volume of this kind-"howto-do-research" books, general bibliographies, style guides, literary bibliographies, library guides, and dissertation lists-are given short, but workmanlike, shrift. Then the compiler settles down to the heart of the matter: guiding the "fledgling investigator" through the best histories, anthologies, books on metrics, dictionaries, and journals in the field, with lists of publishers and book dealers to help the search. Titles are selected on the basis of being "essential" and "current" (i.e., in print and/or available in college and university libraries); cut-off date is mid-1973. There is an author-title index.

Budding Hispanists and mature librarians can both learn much from this book about resources for the study of Hispanic literature and linguistics, though librarians owning Foster and Foster's Manual of Hispanic Bibliography (Suppl. 3BD108) will find its discussion of reference works more indepth. The Sourcebook would benefit from some careful editing (particularly in the chapter on general bibliographic guides and references), and a lower price would put it into more of the hands for which it was intended.-D.G. 
Bromwich, Rachel. Medieval Celtic Literature; A Select Bibliography. [Toronto], Univ. of Toronto Pr., [1974]. 109p. $\$ 8.95$. (Toronto medieval bibliographies, 5) 74-82287.

The latest of the Toronto Medieval Bibliographies, this work follows the threefold aim of the series in providing a basic bibliographic guide for students new to the field, for more advanced readers who have little training in the specialty, and for librarians interested in building a basic collection in the subject covered.

Included are more than 500 books and articles, arranged in five chapters: Introductory materials (bibliographies, collections of texts, etc.); Language; Literary history and criticism; Texts and translations; Background materials (social, cultural, and historical studies). Gaelic and Irish, Welsh, and Breton are covered in each chapter in appropriate subdivisions. Entries carry short evaluative annotations. Emphasis is on native literary tradition in verse and prose from the earliest times to about 1450 , with recent critical works and editions given priority for inclusion, along with older scholarly works of importance. Citations to reviews are a useful feature.R.K.

Chapman, Dorothy. Index to Black Poetry. Boston, G. K. Hall, 1974. 541p. \$25. 748838.

Although this index to poems by and about blacks is described in the introduction as a "complete reference of black poems and poets," by including only ninetyfour books and pamphlets by individual poets and thirty-three anthologies, comprehensiveness is not achieved. However, despite this and the fact that the Index basically includes only American black poetry, it is welcomed as a beginning. A spot comparison between Granger's Index to Poetry and the work under review indicates that, for pertinent authors, the latter indexes many more poems. Three index sections provide access to the poetry: the title/first line index, the subject index, and the author index. Full bibliographic information is given in the title/first line index, with a code which directs one to the list of books indexed. Nonblack authors are indicated by an asterisk. Index to Black Poetry is an important first step in making accessible material which has heretofore been largely ignored. One hopes that the near future will bring an index to black poetry published in serials-an important area which has not yet been covered.-P.A.C.

Woodress, James Leslie. American Fiction, 1900-1950; A Guide to Information Sources. Detroit, Gale, [1974]. 260p. (American literature, English literature, and world literature in English, v.1) \$18. 73-17501.

Addressed to the information needs of those studying American prose fiction of the first half of the twentieth century, this guide is in two parts. Part I, General Bibliography, surveys not only general works of reference, history, and criticism pertaining to the fiction of this period, but also major specialized studies on the novel"Technique and structure," "Themes and motifs," "Foreign reception," etc.- and on the short story. Many of the titles cited are briefly annotated to indicate scope or particular importance.

Part II, which comprises the main portion of the work, is devoted to individual bibliographic essays on forty-four authors, the major body of whose work was written between 1900 and 1950, and "who seem in 1973 to be the most significant producers of fiction" during this period. Concise and up to date (some 1973 works are cited), these essays include a paragraph of biographical and critical summary and sections on (1) Bibliography and manuscripts (including locations for collections of the latter); (2) Works of fiction: novel and short stories (collections of stories only); (3) Editions and reprints; (4) Biography; and (5) Criticism. The essays are quite selective but full of explanatory and evaluative information to guide the student. An index of names includes author-subjects as well as the authors of the biographical and critical works. An unfortunate error appears on the first page of Section I, where the Dictionary of American Biography is cited as the Dictionary of National Biography.-A.L. 


\section{Symbols}

Vries, Ad de. Dictionary of Symbols and Imagery. Amsterdam, North-Holland Pub. Co., [1974]. 515p. \$40. 73-86087.

This interesting work is not a dictionary of rigorous definitions, but, rather, a compendium of connotations, attempting to draw together the wealth of subtle associations that particular symbols and images have accumulated throughout centuries of Western civilization. The scope of the work is broadly defined to include symbols, allegories, metaphors, signs, types, images, common words, proper names, etc., accompanied by their associations in folklore, mythology, literature, religion, heraldry, psychology, or any other context in which they have taken on some special meaning or significance. As a result of covering such a wide range of words and including many more than just the major or most common associations for each one, the "definitions" themselves, though rich and diverse, are brief, sometimes almost to the point of being cryptic.

In its attempt to "prevent too limited an approach to imagery (by showing the ambiguity of many symbols)" (Pref.), the book emphasizes quantity and diversity rather than selectivity or consistency, so that there is no "standard" for the amount or type of information given, even in definitions for words within the same category (e.g., signs of the zodiac). The many citations to written sources provide the reader with the opportunity to clarify and expand his understanding of a word's use; unfortunately, these citations include only the barest minimum of bibliographic information and rely heavily on unkeyed abbreviations.-A.L.

\section{Social Sciences}

Encyclopedia of Sociology. Guilford, Conn., Dushkin Pub. Group, [1974]. 330p. il. $\$ 5.95$ pa. $73-87072$.

Peter J. O'Connell, ed.

Addressed to the layman and designed "to fill specific informational needs [in the field of sociology] as clearly, comprehensively, and concisely as possible" (Pref.), this dictionary of some 1,300 articles covers terminology, sociological theories, institutions of society, concepts, historical ma- terial, biographies of social scientists of the past and present, and research findings in the related social sciences of psychology, economics, anthropology, political science, and history.

Entries are short (up to 2,500 words), specific, and arranged in one alphabet; all but the briefest are signed. There is no index, but a vigorous effort has been made to substitute for one through the liberal use of see also references; "subject maps" and "item guides," devices showing relationships and organization of specific articles within a large subject; and "consult references" directing the user to titles in the substantial bibliography that concludes the work. Graphs, charts, tables, and photographs are used to advantage throughout on a three-column page, two devoted to text and one to illustration. Work has already begun on a revised edition. Libraries at every level will welcome this addition to the reference collection. - R.K.

\section{Pine-Coffin, R. S. Bibliography of British} and American Travel in Italy to 1860. Firenze, Olschki, 1974. 371p. facsim. (Biblioteca di bibliografia italiana, 76)

Students of social history will be interested in this bibliography of first-hand accounts of Italy by British and American travelers over a period of more than 400 years. A long introductory essay is followed by two chronological lists, one British (which includes some translations of continental authors), the other American; each is arranged by date of journey and incorporates bibliographical details of first publication together with a brief descriptive annotation. A third, considerably shorter, section is devoted to works on the value and purpose of travel. Only general travel accounts have been selected; those devoted to special subjects have been excluded, as have imaginative verse and prose. Indexes of persons; anonymous titles; places; publishers, printers, and booksellers add reference value. $-R . K$.

Pino, Frank. Mexican Americans; A Research Bibliography. [East Lansing], Latin American Studies Center, Michigan State Univ., 1974. 2v. \$10 pa. 74-620088. In accordance with its aim to be an "in- 
terdisciplinary guide to the study of the Mexican American," this bibliography covers a wide range of materials. Books, articles, master's theses, doctoral dissertations, government documents, and films are listed by author within thirty-five subject groupings. These run the gamut from traditional fields of study such as "sociology" and "anthropology" to newer areas such as "cinema-television," "images," and "Mexican American literature." Scholars will be especially grateful for bibliographical guidance in these less well-trodden areas. Liberal cross-references between the sections increase the usefulness of the work, although a detailed subject index would have been preferable for some purposes. For instance, the "Bibliography" section will be a help to librarians and researchers, but because of its length (sixty-seven pages) the lack of a subject index makes using it a tedious process. The faults of the bibliography, however, are far outweighed by the scope and depth of its coverage, and any scholar doing research in Mexican American studies should certainly consult it.D.A.S.

Women's Rights Almanac, 1974- . Nancy Gager, ed. Bethesda, Md., Elizabeth Cady Stanton Pub. Co., 1974- . 620p. \$4.95. 74-77527.

This almanac, the first of what one hopes will become a long annual series, is crammed with names, addresses, statistics, biographies, chronologies, bibliographiesalmost a report on the status of the women's rights movement. The volume begins with a state-by-state survey giving for each state, the District of Columbia, and United States territories, demographic information and a directory of elected women officials, women's organizations, commissions, and social service agencies. The next section does the same at the national level, adding information on federal legislation affecting women. A collection of essays relating to various women's issues follows, each essay concluding with a list of sources for further information. These lists are supplemented by book lists and a bibliography of bibliographies. There is a detailed index. And all this for $\$ 4.95 !-E . M$.

\section{Political Science}

Kanet, Roger E. Soviet d East European Foreign Policy; A Bibliography of English- \& Russian-language Publications 1967-1971. Santa Barbara, Calif., ABC Clio, [1974]. 208p . \$15.75. 73-76444.

Employing an author arrangement with detailed subject index, this bibliography lists more than 3,200 references to books and periodical articles. The compiler has aimed at inclusiveness; entries are not annotated. Articles were drawn from about 180 periodicals, and "all non-Soviet items published in English noted by the editor are included," as are all "Russian-language and Soviet-published materials that concern Soviet or East European foreign policy directly."-Pref. Also included is "a selection of Soviet books and articles which deal primarily with such general topics as developing countries and imperialism and also concern Soviet or East European foreign policy." Russian-language items are given in transliteration, with a translation of the title supplied in brackets.

Belated appearance of volumes of the American Bibliography of Slavic and East European Studies covering 1967-72 has somewhat alleviated the need for recent bibliographic coverage in the area of Soviet and East European foreign policy, but Kanet's compilation will be useful both for its cumulative aspect and for the more specific subject approach which it provides.E.S.

Khalidi, Walid and Khadduri, Jill, eds. Palestine and the Arab-Israeli Conflict; An Annotated Bibliography. Beirut, Institute for Palestine Studies, 1974. 736p.

Although they have gathered only a "core of sources" on the Palestine question and based their work entirely on the library resources of Beirut, the editors seem to have exploited these resources fully and intelligently in their aim of building a base for future bibliographic work on this topic. Indeed, they intend to carry on that work themselves by producing supplements every five years.

All the material is related to political life; thus, religious and physical topics are excluded unless they are otherwise relevant. 
As reflected in the title, Palestine's role in the conflict is the central concern, and the material is arranged by subject, era, and the role of other groups (other Arabs, Zionists, Israelis, Great Powers, international bodies, etc.) during the 1880-1971 period. Within nine major subject sections and four major time periods there are more than a hundred subdivisions. Special sections are provided for: General sources; Historical background; and The Palestinian people, 19481967 and 1967-1971. Many cross-references attempt to tighten this arrangement and to compensate for lack of a subject index. Entries include an English translation of foreign-language titles, notes on the language of the work, and full citation to any translation. Most entries are succinctly annotated either with a summary of content or a judgment of research value. The majority of sources selected for this bibliography will be available in research libraries around the world (many government documents, United Nations publications, journal articles, etc., are included) and it should prove a useful compilation.-M.A.M.

Mackie, Thomas T. and Rose, Richard. The International Almanac of Electoral History. New York, Free Pr., [1974]. 434p. \$15. 74-11577.

The purpose of this work, according to the introduction, is to "provide a complete and accurate compilation of election results" in twenty-three Western nations. The countries selected represent those industrial societies which have held regular competitive elections since the end of World War II. For each country a brief historical summary of the electoral system and laws is given. Next comes a list of the political parties, followed by a list of the exact dates of each election. Finally, election results are given by total number and percentage of votes for each party and the number and percentage of seats that each party won. For countries with bicameral legislatures, election results for the "most important" house are given. Sources are cited at the end of each section.

The Almanac is helpful in bringing together in compact format information for which one would otherwise have to consult several sources. However, there are omis- sions which should be noted. First, it omits precisely those countries for which election statistics are most difficult to locate, namely African, Asian, Latin American, and East European nations. (The only country included from these regions is the Republic of South Africa.) Also, although claiming to give complete election results for the countries selected, statistics for only one branch of government are usually given. Thus, the chapter on the United States deals only with the presidential races; omission of figures for congressional races results in an incomplete and sometimes misleading picture. The same criticism is probably applicable to other countries. This volume is one of a series on electoral behavior sponsored by the International Political Science Association and the International Sociological Association; one hopes that future studies will retain the positive qualities of this one while rectifying its omissions.-P.A.C.

\section{GeOGRAPHY}

Harris, Chauncy D. Guide to Geographical Bibliographies and Reference Works in Russian or on the Soviet Union; Annotated List of 2660 Bibliographies or Reference Aids. Chicago, Univ. of Chicago, Dept. of Geography, 1975. 478p. maps.

(Chicago. Univ. Dept. of Geography.

Research paper, no.164) \$5. 74-84784.

Addressed to those "who wish to become informed on the corpus of serious scientific work in geography and related disciplines published in Russian ... or dealing with the geography of the Soviet Union," this work presents "a relatively comprehensive inventory of bibliographies published in the Soviet Union on all fields of geography" and includes "a selection of the more important reference materials in Russian of particular geographic value, such as atlases, statistical sources, encyclopedias, handbooks, gazetteers, geographical dictionaries and biographical directories" (Pref.). It reads, in fact, like a Winchell of Russian geography.

Coverage is primarily of $1946-1973$ publications, with earlier works listed selectively. Bibliographies separately published and those in major monographs (listing more than a hundred references) are included. 
A classed arrangement is followed under these main divisions: General bibliographical aids; Reference works and associated bibliographies; Systematic fields of geography (i.e., physical, economic, history, methods); Regional geography: the Soviet Union; Regional geography of areas outside the Soviet Union; Bibliographies and reference works on the Soviet Union in Western languages; Note on sources. While the book's principal audience will, of course, be interested geographers, librarians will find useful the identification and descriptions of hundreds of social science sources. Entries include full bibliographical information, translation of title, and descriptive annotation. An index of authors, titles, sponsoring institutions, subjects, and places adds reference value.-R.K.

\section{History and Area Studies}

Abajian, James de T., comp. Blacks and Their Contributions to the American West; A Bibliography and Union List of Library Holdings through 1970. Boston, G. K. Hall, 1974. 487p. \$29.50. 74-8695.

This solidly impressive bibliography notes and locates materials by black authors and about black activities in Alaska, Arizona, California, Colorado, Hawaii, Idaho, Montana, Nevada, New Mexico, Oregon, Utah, Washington, and Wyoming. The great majority of its over 4,300 items were located in a survey of 155 California libraries; roughly twenty-five other libraries, principally in the western United States but also including the Library of Congress, Howard University, and the Schomburg Collection, contributed other titles; still others were found in newspaper or wire services offices, private collections, etc. According to the compiler, the preponderance of California-related titles is due to its long history, proportionately larger black population, and the analysis of the 1965 Watts riots; also, the initial impetus and funds for the bibliography were supplied by the Friends of the San Francisco Public Library.

Mr. Abajian has eschewed general black studies books and sources listed in the Readers' Guide and the Index to Periodical Articles by and about Negroes in favor of local imprints, specific information, and obscure titles unlikely to be picked up in general bibliographies; the exception is the inclusion of all titles of Western black authorship other than scholarly work in African studies. Cited are: books and parts of books; periodical and newspaper articles; federal, state, and local government documents; doctoral dissertations and master's theses; oral history tapes, typescripts, and other manuscripts; and ephemeral materials, e.g., term papers, booksellers' catalogs, scrapbooks, broadsides, legal transcripts, publications by private associations, etc. Very brief descriptive notes are sometimes given to clarify content. A list of black periodicals and newspapers from the region is followed by an author/subject index.

The compiler laments the lack of attention, staff, and funding given to the acquisition of local and regional imprints and primary source materials in the Western states. He also indicates that only the California State Archives have been investigated in any detail for this compilation, and further research would probably uncover many valuable collections. Despite the modest disclaimer that this is not a "definitive" bibliography, it is a valuable contribution and will probably encourage the collection and utilization of resources in the field. $-D . G$.

\section{Encyclopedia of Latin America. Ed.}

by Helen Delpar. N.Y., McGraw-Hill, [1974]. 65lp. il. \$29.95. 74-1036.

More than a hundred scholars, mainly from United States colleges and universities, have contributed to this new compilation which is intended as a "comprehensive yet concise reference book offering authoritative information on the history, economy, politics, arts and other aspects of Latin America."-Introd. It treats the eighteen Spanish-speaking republics plus Brazil, Haiti, and Puerto Rico, with a survey article included for each of these countries. Emphasis is on the national period of Latin American history, but attention is given to important colonial figures, events, and institutions. An alphabetical arrangement is employed, and there are numerous see and see also references. Articles are signed; only the longer ones include bibliographical ref- 
erences. Thus, biographical sketches of figures in literature and the arts seldom include suggestions for further reading, although a "Select bibliography of bibliographies" (p.649-51) is intended as partial compensation for this lack.-E.S.

Encyclopaedia Rhodesia. Contributing editors: Peter Bridger [and others. Salisbury, Rhodesia, College Pr., 1973]. 448p. \$12.50. 74-165100.

Although the editors have made no claim to comprehensiveness, this volume brings together information on Rhodesia, which, were it available at all in other sources, would have to be retrieved with considerable effort. The work is divided into three sections. The first and most lengthy is the "encyclopedic" section, which is an alphabetic listing of short, unsigned entries dealing with all aspects of Rhodesian life. A major emphasis has been placed on flora and fauna, but there are numerous entries which deal with geography, biography, and the structure of the central government. This section is well illustrated with drawings and photographs, and each geographic entry has been keyed to a large foldout map in the second section. The relatively short map section serves as a mini-economic-atlas of Rhodesia. The appendixes which make up the last section include statistical tables, historical documents, lists of principal administrators, and a chronology. As the first work of its kind devoted to Rhodesia, the ready-reference value cannot be minimized. However, one would hope that in future editions, instead of blanket acknowledgments to government agencies, exact citations to sources of statistical tables, etc., be given.-B.W.

Pearson, James Douglas, ed. A Bibliography of Pre-Islamic Persia. [London], Mansell, 1975. 288p. (Persian studies ser., 2) \&11.

About 7,300 items are included in this bibliography which employs a classed arrangement with author index. There are four principal sections, each with appropriate subdivisions: (a) Languages and literatures; (b) History; (c) Religion; and (d) Art and archaeology. A full table of contents facilitates use, but there is no detailed subject index. The compilation "represents an attempt to include all the [relevant] printed literature available in western European languages" (Introd.), with the addition of selected publications in Persian. Spot-checking turned up no publications later than 1970; items not examined by the compilers are marked with an asterisk. There is a list of periodicals consulted (with indication of dates of coverage) and another list of "Festschriften and collective works consulted."-E.S.

Stember, Sol. The Bicentennial Guide to the American Revolution. N.Y., Saturday Review Pr., E. P. Dutton, 1974. 3v. 7323108.

Contents: v.1, The war in the North, from Fort Ticonderoga to Concord Bridge. 391p. \$4.95; v.2, The middle colonies, from Washington Crossing to Valley Forge. 173p. \$3.95; v.3, The war in the South, from Savannah to Yorktown. 217p. \$3.95.

Mr. Stember has visited over 600 sites of Revolutionary War battles in order to provide as complete a description as possible of each site for the armchair traveler and the vacationer. He compares the battlefield as it is now with the battlefield as it appeared 200 years ago, placing the descriptions in a geographically arranged narrative detailing the campaigns and the events of the war in the individual states and cities.

Though not a conventional reference book, there is much factual information here to supplement Boatner's Encyclopedia of the American Revolution (e.g., that the site where Nathan Hale was hanged was 46th Street and 1st Avenue in New York City). Most libraries will want these volumes in a circulating collection, and some may not feel they can afford the luxury of adding another set of this very readable touring guide to the reference collection.E.M.

U.S. National Archives and Records Service. Guide to Materials on Latin America in the National Archives of the United States, by George S. Ulibarri and John P. Harrison. Wash., 1974. 489p. \$7.85. 74-600051.

This work supersedes the 1961 volume 
of virtually the same title (Guide DB114). The companion volume promised for the earlier publication was never issued; and, as the first volume was out of print, it was decided to issue a new guide to Latin American source materials in the National Archives. The new guide incorporates entries from the 1961 work along with "descriptions of pertinent records of the executive, legislative and judicial branches of the government that were not included in the earlier guide" (Introd.). The descriptions are detailed, giving size of the collection, indexes or finding aids, specific restrictions on the file, and an extensive discussion of representative documents "in sufficient detail, both as to type and content, so that the reader can reasonably be expected to determine the value for his purpose of other records in the group or series described." There is an index of issuing bodies, geographic names, and significant subjects, plus appendixes giving lists of National Archives files available on microfilm, and lists of diplomatic and consular posts with archival records. For the 1961 edition the diplomatic and consular post records were described by means of two folded maps which are not included with the new edition; since these are useful graphic representations, librarians may want to keep them with the 1974 volume.

Research workers in Latin American studies will be pleased to have these great archives so well described, and the National Archives and Records Service is to be congratulated on another in its continuing series of finding aids. $-E . M$.

\section{Writings on American History; A Subject} Bibliography of Articles, 1973/74- . Wash., American Historical Assoc.; Millwood, N.Y., Kraus-Thomson, 1974- . Annual. ([v.1] 266p., \$13.50) 74-13435.

James J. Dougherty, compiler-editor.

The last volume of the previous series of Writings on American History (Guide DB25) covered the year 1960 and was published in 1972. The great time lag was a matter of some concern to historians, and the decision to try a different approach has resulted in this new series. In this first volume, articles cited in the "Recently Published Articles" section of the American
Historical Review for the period June 1973June 1974 have been assigned subject headings and arranged in a chronological, geographical, and subject framework; there is an author index. Rather than risk increasing the time lag, entries were not annotated.

The list of journals at the beginning of the volume includes a number of foreignlanguage journals and some conference and symposium papers. In future volumes the editors hope to be able to add books, dissertations, and Festschriften as well as more journals. Librarians and researchers will be grateful to the association and the publisher for their efforts to cope with the problem of currency; that they did not succumb to the temptation of indexing by keyword-intitle is a blessing. One hopes that a detailed topical index will be added in later volumes.

What are the plans for covering the interim years? The American Historical Association has announced that Writings on American History, 1961, is in press; $1962-$ 1973 will be covered by a cumulative bibliography to be published by Kraus-Thomson later this year. The new series will be continued annually.-E.M.

\section{New Editions and Continuations}

Having outgrown the two-volume format of the eleventh edition (1968; Suppl. 3AA 31), the twelfth edition of The Reader's Adviser is to be in three volumes. Volume one, covering "the best in American and British fiction, poetry, essays, literary biography, bibliography, and reference," has appeared under the editorship of Sarah L. Prakken (N.Y., Bowker, 1974. 808p. $\$ 23.50$ ). "For the first time the work of revising each chapter of the first volume of this edition has been entrusted to a single editor who has special expertise in the area of his chapter."-Pref.

Jean Peters is the editor of the fifth edition of The Bookman's Glossary (N.Y., Bowker, 1975. 169p. $\$ 10.50$ ), a revised and expanded edition in enlarged format. The appendix of terms from the foreign book trade found in the previous edition (Guide AA227) has been omitted since this information is readily available in volumes devoted to that topic. 
Subject Collections; A Guide to Special Book Collections and Subject Emphases, compiled by Lee Ash, has appeared in a fourth revised and enlarged edition (N.Y., Bowker, 1974. 908p. \$38.50). The work is now computer-produced to make for easier expansion and updating of future editions; yet, despite wider coverage in the new volume, the editor points out that some listings from the previous edition (Suppl. 2AB13) have been dropped for various reasons (e.g., at the request of the holding library or because a library failed to respond to the compiler's questionnaires).

The third volume of the German-English part of Harrap's Standard German and English Dictionary, covering L-R, has now appeared (London, Harrap, 1974. \& 15). Like the previous volumes (Guide AE271; Suppl. 2AE42), this one was edited by Trevor Jones.

Biographical sketches of more than 38,000 scholars appear in the sixth edition of the Directory of American Scholars (N.Y., Bowker, 1974. 4v. \$148.50). The fourvolume division follows that of the previous edition (1969; Suppl. 3AJ9); cross-references are again supplied for figures active in more than one discipline; and a complete alphabetical index of biographees appears in volume four. A new feature is the geographic index at the end of each volume.

Nearly 590 numbered items are included in the fifth edition of Richard D. Altick and Andrew Wright's Selective Bibliography for the Study of English \& American Literature (N.Y., Macmillan, 1974. 168p. $\$ 2.95$ pa.). As in earlier editions (Suppl. 2BD 44), alternate pages of the bibliographic section of this now standard guide are left blank for student notes.

Theses and Dissertations on Asians in the United States, compiled by Paul M. Ong and William Wong Lum (Davis, Asian American Studies, Dept. of Applied Behavioral Sciences, Univ. of Calif., 1974. 113p. $\$ 3.50$ pa.) represents a major revision and expansion of Lum's Asians in America (1970; Suppl. 3CC19). It lists 1,372 items in topical arrangement, with keyword and author indexes. Frederick J. Dockstader's The American Indian in Graduate Studies; A Bibliography of Theses and Dissertations first appeared in 1957 (Guide
CC67); it was reprinted in a second edition in 1973, omitting the addenda, p.36264 , and the index. A companion volume designated as "Part 2" has now appeared (N.Y., Museum of the American Indian, Heye Foundation, 1974. 426p.; Museum Contributions, v.15, pt.2), covering theses and dissertations of 1955-70. It continues the item numbering from the main section of Part 1 (i.e., beginning with item 3,660) and incorporates the addenda from the original volume into the alphabetical author sequence of Part 2. A new index to both volumes is provided; the total number of entries is now 7,446 .

"Edition 5" of The Foundation Directory (Guide CA35) has recently appeared under the editorship of Marianno O. Lewis (N.Y., Foundation Center, 1975; distr. by Columbia Univ. Pr. 516p. \$30). This edition lists 2,533 foundations having either $\$ 1$ million or more in assets or $\$ 500,000$ or more in grants reported. Arrangement follows that of the fourth edition (1971), with the addition of a new supplementary index which lists foundations under the cities in which they are located. Four supplements "are planned for the period before appearance of Edition 6 in 1977."-Introd.

A "two-in-one" publication entitled $\mathrm{Bu}$ reau of the Census Catalog of Publications: 1790-1972 (Washington, 1974. 320p., 591p. \$7.10) reprints the bureau's Catalog of United States Census Publications 17901945 (1950; Guide CG42) and adds a new section covering some 6,000 bureau publications of the 1946-72 period. This latter section is based primarily on the annual issues of the bureau's Catalog (Guide CG41) for the years in question. Each of the two sections has its own index.

The revised edition of Walter Laqueur's A Dictionary of Politics (N.Y., Free Pr., 1974. 565p. \$14.95) includes references to events and new developments through early 1973. The "Bicentennial Edition" of Mark Mayo Boatner's Encyclopedia of the American Revolution (N.Y., McKay, 1974. 1290p. $\$ 17.50)$ is a reprinting, with minimal changes and emendations, of the 1966 edition (Suppl. 1DB3). A few bibliographic references to recent publications have been supplied in the text, but apart from a brief "Addendum" (p.1273) the general bibliog- 
raphy has not been updated.

Admiralty Officials, 1660-1870, compiled by J. C. Sainty (London, Athlone Pr., 1974. 161p.) forms the fifth volume of the series Office-Holders in Modern Britain. As in the preceding volumes, chronological lists by offices and departments are followed by an alphabetical list of officials; again, a scholarly introduction and useful notes are features.

The fourth edition, revised and expanded, of Robert G. Albion's Naval \& Maritime History; An Annotated Bibliography (Newton Abbot, David \& Charles, 1973. 370 p. \&6.95) combines the listings from the third edition (1963; Suppl. 2EI32) and its two supplements with new listings for works published through mid-1971. More than 5,000 entries are now included.
After having undergone a number of changes of title, frequency, etc., the American Chemical Society's List of Periodicals (Guide ED12) is now appearing as the CAS Source Index. The "1907-1974 cumulative" (Columbus, Ohio, Chemical Abstracts Service, 1975. 2v. \$200) "cumulates nearly 40,000 entries into one alphabetical sequence and carries title abbreviations based on international standards." As before, entries are arranged alphabetically, letter-by-letter, according to abbreviated form of the title; locations of files are indicated for 398 libraries (326 in the United States; 72 in foreign countries). Quarterly supplements are available at $\$ 100$ per year, and CASSI is also available in computerreadable form.-E.S.

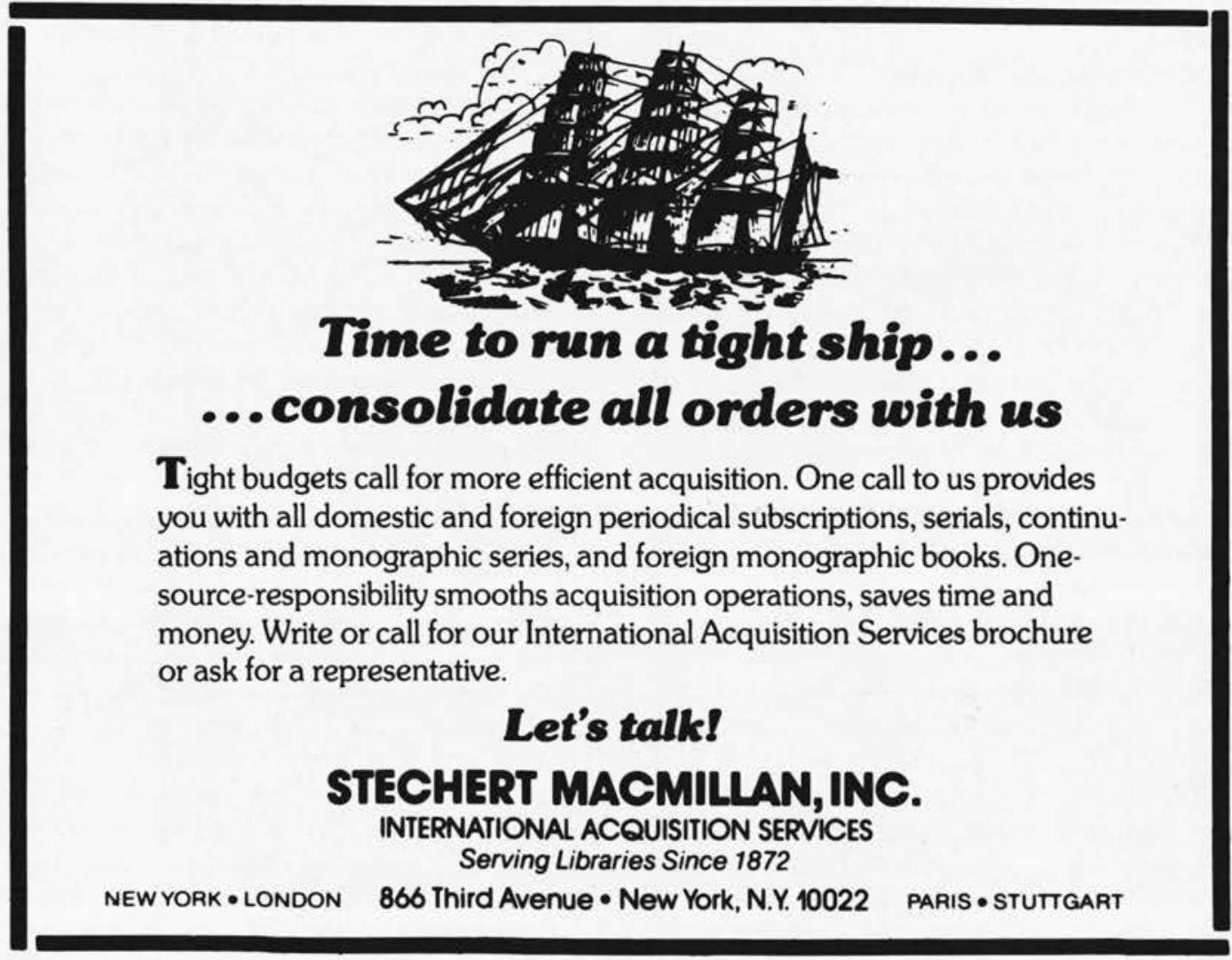




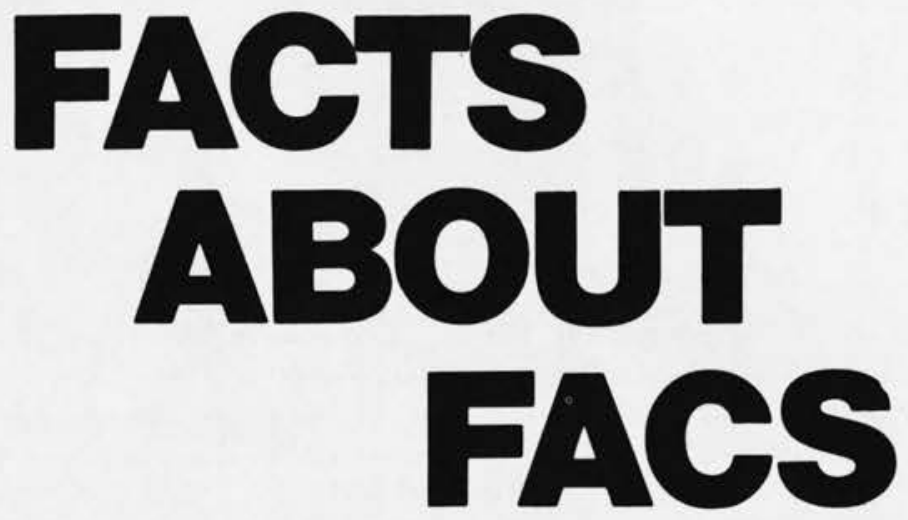

Fact 1: FACS stands for Faxon's Automated Claim System

Fact 2: FACS is a new automated system intended to make life a lot easier for you.

Fact 3: To place a claim, all you do is complete and return our claim notice form. We then activate our computer to process the claim to the publisher with complete order and payment information included.

Fact 4: You receive a quarterly report of all your claim request activity.

Fact 5: This is only one reason, among many, why you should choose Faxon, the world's only fully automated library magazine subscription agency. For particulars, write for a copy of our Service Brochure and annual Librarians' Guide to Periodicals. Or call us on our toll-free line: 1-800-225-7894.

Library business is our only business - since 1881.

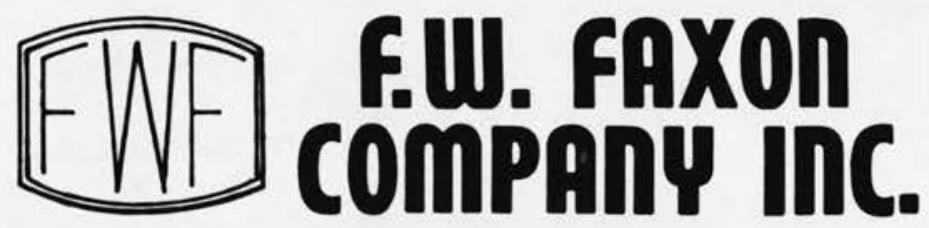

15 SOUTHWEST PARK, WESTWOOD, MASS. 02090 